\title{
Camel management as an adaptive strategy to climate change by pastoralists in southern Ethiopia
}

\author{
Galma Wako', Menfese Tadesse ${ }^{1}$ and Ayana Angassa ${ }^{2 *}$
}

\begin{abstract}
Introduction: Experiences of low rainfall and frequent droughts have had enormous impacts on livestock production and pastoralists' livelihoods in southern Ethiopia. The Borana pastoralists are dependent on livestock husbandry with the dominance of cattle in their herds for generations. Recently, the Borana communities have engaged in extensive livestock species diversification, with more focus on camel management as an adaptation strategy to the severity of recurrent droughts. Although increasing interests in camel management among the Borana pastoralists are acknowledged, the driving forces for the increase in camel population in the region have not been addressed. The aim of this study was to assess the trend in camel management as an adaptation strategy towards climate change among the Borana pastoral households. The study also investigated evidence of climate change and the driving factors for camel adoption.

Methods: The study was conducted in three purposively selected kebeles, which is a lower administrative unit in Ethiopia, of Yabello district in Borana Zone in southern Ethiopia focusing on 156 randomly selected camel-owning households. The study employed both quantitative and qualitative methods whereby data gathering tools such as key informant interviews (KII), focus group discussions (FGD), household surveys (HS), and field observations were used. The data were analyzed by descriptive statistics using SPSS software version 16.
\end{abstract}

Results: Pastoralists' perceptions and the existing meteorological data analysis showed an increasing trend in temperature but a decreasing pattern in rainfall over the last 27 years (i.e., during the last four Gada periods). Both pastoralists' observations and existing meteorological data analysis showed an increasing incidence of recurrent droughts with decreasing availability of grazing and water resources. Respondents further explained that cattle are more vulnerable during severe droughts. The findings also showed that camel management as an adaptation strategy by the Borana pastoralists began recently and showed a steady increase in trend over the last four Gada periods. Pastoralists' perceptions and the existing analysis confirmed that camels' potential for high milk production and their capacities to withstand harsh environmental condition are among the many reasons that contributed to the adoption of camels by pastoralists in southern Ethiopia. Camels were also more preferred with the changing ecology of rangeland vegetation dynamics towards bush encroachment.

Conclusions: It seems that the high potential of camels for milk production and their abilities to withstand harsh environmental conditions are the major driving forces that contributed to the adoption of camels by pastoralists in southern Ethiopia. Hence, the adoption of camels by pastoralists in southern Ethiopia could be best understood in terms of livelihood diversification option to ensure the food security of pastoral households. We conclude that the increase in camel population in Borana during the last four Gada periods could be attributed to communities' responses to the impact of climate change and frequent droughts.

Keywords: Climate change, Camel management, Pastoral households, Borana Zone, Southern Ethiopia

\footnotetext{
*Correspondence: ayana.angassa@gmail.com; aabdeta@bca.bw

${ }^{2}$ Department of Animal Science and Production, Botswana University of

Agriculture and Natural Resources, Gaborone, Botswana

Full list of author information is available at the end of the article
} 


\section{Introduction}

Globally, climate change is one of the most important environmental issues and challenges of the twenty-first century (UNFCCC 2007). Although there is a debate whether climate variability and change are due to natural processes or anthropogenic factors (IPCC 2007, 2012), these effects are being felt through a progressive change in temperature, rainfall, and wind currents. According to IPCC (2001), the average global surface temperature is increased by $0.6{ }^{\circ} \mathrm{C}$ during the twentieth century. In the drylands of Africa, environmental shocks and stresses are considered among the biggest challenges to the pastoral communities (Watson et al. 2016). In arid and semi-arid landscapes of Africa, meteorological records indicate that there has been a substantial increase in temperature and reduction of rainfall since the early 1990s (Naess et al. 2010; Oba 2014). In Ethiopia, climate variability and change have resulted in frequent droughts, floods, heavy rains, strong winds, and heat waves (Abebe 2007).

The Borana pastoral areas of southern Ethiopia are prone to frequent droughts (Desta and Coppock 2002). Droughts are usually upsetting the delicate balance on which the pastoral production system depends (Desta and Coppock 2002; Angassa 2011). According to the observations of Borana elders, drought is a prolonged period of months or years in which rainfall is absent leading to high mortalities of livestock. According to the World Meteorological Organization (Hounam et al. 1975), droughts are classified as either meteorological (lack of precipitation over a region for a period of time), hydrological (a period with inadequate surface and subsurface water resources), agricultural (a period with declining soil moisture and consequent crop failure due to lack of surface water resources), or socioeconomic (failure of water resource systems to meet demands impacting human activities both directly and indirectly). Generally, frequent droughts can cause a big challenge for the livelihoods of pastoralists in southern Ethiopia, where pastoralists are dependent exclusively on cattle production for generations.

In recent decades, the impact of climate variability on cattle survival and livelihoods of pastoralists has led to substantial shifts in the composition of livestock herds among Borana pastoralists in southern Ethiopia (Megersa et al. 2014). In response to the challenges that Borana pastoralists are facing today, they practice a number of adaptive strategies. These adaptive strategies include livestock diversification, crop faming, establishment of community or private enclosures, and increase of alternative sources of income such as charcoal making. Thus, among the various adaptive strategies by the Borana pastoralists, this study focuses on camel management as an adaptation strategy to climate change.

The impact of climate change has had intended consequences on rangeland degradation with important socio-cultural structures that are also aimed at managing rangeland resources (Coppock 1994; Oba 1998; Haile and Yilma 2009). The declining trends of precipitation, combined with successive droughts, have led to a chronic water scarcity across the region (Hartmann and Sugulle 2009). Such large-scale and multi-faceted resource degradation implies a profound problem for cattle production and sustainability of pastoral livelihood among the Borana pastoralists in southern Ethiopia (Tache 2010).

The Borana pastoral system was one of the few sustainable livestock production systems in eastern Africa. Currently, the Borana pastoral system has suffered greater cattle die offs due to recurrent droughts. Grazing resources are deteriorating with increasing bush encroachment and declining in forage production. The effects of droughts and bush encroachment are major drivers of forage scarcity, causing cattle mortality in southern Ethiopia. In the past, a stable system of rangeland for seasonal grazing was related to the vast and spatial distribution of resources. Seasonal movements of stock and use of different landscapes between the dry and wet season grazing areas were the most common features of land use. The Borana rangeland is composed of key grazing resources associated with the traditional deep water wells. From pastoralists' perspectives, the landscapes of the deep well rangelands are special varieties of savanna grasslands with permanent water sources. In these landscapes, the $20-\mathrm{km}$ radius of the wells is excluded from grazing during wet seasons (Tiki et al. 2013). On the contrary, the waterlimited rangelands were used during the wet season. For the last three and a half decades, however, these former wet season rangelands have been made more accessible through the development of ponds to collect rain water. The creation of water ponds attracted more settlements that is associated with heavy grazing pressure and greater scarcity of grazing resources. Recently, the Borana pastoralists have been engaged in livestock diversification, with more focus on camels. The vulnerability of cattle to frequent droughts is the major reason for the adoption of camels. Oral history indicates that camels have been adopted by the Borana pastoralists during the Gada of Abay Horro (1560-1568) following a period of severe drought (Angassa and Oba 2008). Therefore, the notion of climate change is not new to the Borana pastoralists. However, what may be new is that why these pastoral societies have shifted from cattle production to camel management having large numbers as compared to the past. These management 
strategies may represent adaptation to copy with the recurrent droughts.

Currently, camel management is considered as the source of livelihoods of many pastoralists in Borana areas of southern Ethiopia. The life of pastoralists is not only affected by risks associated with climate uncertainty and recurrent drought but also influenced by livestock diseases, which are worsened by the impact of climate change that causes more deaths of livestock (Gardner 2012). Besides the impact of climate change (Megersa et al. 2014), changes in the ecology of savanna grasslands due to bush encroachment (Angassa and Oba 2008), impacts of recurrent droughts, and problems of cattle mortalities (Angassa and Oba 2007; Angassa 2011) are among the major drivers for livestock diversification by pastoralists. These factors have adversely affected milk production and the livelihoods of pastoralists (Calvosa 2009; Megersa et al. 2014). Between 1980 and 2000, three major drought periods struck the lowlands of Borana pastoral areas, which decimated up to two thirds of the cattle population (Desta and Coppock 2002).

Pastoral communities have developed various traditional adaptation mechanisms over the years to minimize their vulnerabilities to the impacts of climate variability (Omolo 2010; Tache 2010). One of these mechanisms is diversification of livestock species by increasing confidence in camels and other drought-tolerant livestock species (Hesse and Cotula 2006). The adaptation strategies of eastern African pastoral communities to climate variability have been well documented for decades (Ellis and Swift 1988; Oba 1998; Campbell 1999; McCabe 2006). Previous evidence (Opiyo et al. 2015) has also shown that the Turkana pastoralists in northern Kenya are using a variety of strategies to adapt to climate variability. According to the same authors, adaptation strategies to climate variability among the Turkana pastoralists in northern Kenya included diversification of livelihood sources, livestock mobility, and diversification of herd composition to benefit from the varied drought and disease-tolerant animals.

In terms of camel population, eastern Africa is home to $60 \%$ of the world's camel population (Musinga et al. 2008). Ethiopia has approximately two million camels (CARE 2009), all owned by the pastoral communities (SOS Sahel 2010). The importance of camels has risen as a result of an increasing appreciation of their potential for milk production and ability to adapt to climate change (FAO 2010). The popularity of camel products in Somalia, Ethiopia, Sudan, and Kenya has also rapidly increased in recent years due to their contribution to the livelihoods of pastoralists and food security under harsh environmental conditions (Ahmed and Kanwal 2004; Ahmad et al. 2010). In Kenya, camel management is a recent experience, which has been adopted by the Maasai, Borana, Samburu, and Pokot pastoralists. Similarly, in Ethiopia, camel management has been newly adopted by the pastoral communities in Shinile and Guji Zones (Riché et al. 2009; Wako 2015). The practice of camel management by pastoralists as an adaptation strategy to climate change is associated with the responses of communities to the impact of multiple droughts on cattle herds. Camels can successfully survive and remain productive under harsh environmental conditions (Ahmed and Kanwal 2004). During drought years and dry season periods when milk production from cows and goats becomes inadequate, camels remain reliable sources of milk for pastoralists. Moreover, in areas where water scarcity is the biggest challenge, camels are quite adapted and can stay for extended days without water (Farah 1996). Such qualities of camels have attracted the interests of the non-camel herding pastoralists towards camel management as an adaptation strategy under changing climate.

Megersa et al. (2008) have reported some production and reproductive performances of camel in Borana area. However, their study did not show issues related to camel management as an adaptation strategy to climate change except that performance in pastoral camels may be enhanced by understanding the traditional management practices and health aspect of the animal. Although the increase in camel herding in Borana area is already apparent (Megersa et al. 2008), the driving factors for camel management as an adaptation strategy and the linkage to climate change have not been adequately addressed in southern Ethiopia. So far, there is no information on camel management as an adaptation strategy to climate change by the cattle pastoralists in southern Ethiopia. Therefore, this study had investigated camel management as an adaptation strategy to climate change by Borana pastoralists. In particular, the study addressed two basic questions: (1) What evidence is documented on the trend of climate change by meteorological records versus pastoralists' perceptions in the study area? (2) What are the driving factors that lead to an increase in camel management as an adaptation strategy by pastoralists in the study area? Therefore, the objective of the study was to investigate the evidence of climate change and trend of camel management as an adaptation strategy among the Borana pastoralists in southern Ethiopia. We hypothesized that (1) there is no sufficient difference between meteorological records and pastoralists' perceptions in predicting the trend of climate change that trigger camel management as an adaptation strategy and (2) meteorological records are better than pastoralists' perceptions in predicting the trend of climate change that drive camel management as an adaptation strategy. 


\section{Methods}

\section{Study area}

The study was conducted in Yabello district of Borana Zone, southern Ethiopia. The study area is classified as arid and semi-arid rangelands, with pockets of subhumid zones (Coppock 1994). The rainfall is bimodal with a mean annual rainfall of $500 \mathrm{~mm}$ with considerable inter-annual variability (Angassa and Oba 2007). Most annual rainfall $(60 \%)$ occurs during the main rainy season (March to May), with 30\% occurring in the short rainy season (September to November) (Coppock 1994), while $10 \%$ with occasional rains. The longest dry period, from December to February, is known locally as "Bona" season and the cold dry period, June to August, is called "Adolessa" season. The mean annual temperature is $24{ }^{\circ} \mathrm{C}$ with a minimum and maximum temperature of 17 and $28{ }^{\circ} \mathrm{C}$, respectively (Coppock 1994). The rangelands are dominated by savanna vegetation, with varying proportion of open grasslands consisting of perennial herbaceous and woody vegetation (Angassa and Oba 2008). The Borana pastoralists are dependent on pastoralism and agro-pastoralism, where livestock production remains the main sources of food, income, and social prestige (Legesse 1973).

Traditionally, the Borana pastoral system of southern Ethiopia is based on cattle husbandry for survival and income generation. This traditional system of cattle production had been effective over generations in producing animal products with a robust management and maintenance of rangeland resources (Oba 1998). In recent years, due to the impact of climate change, the Borana pastoralists have started to gradually diversify livestock and vary the composition of their herds to match the local environmental conditions (Megersa et al. 2014; Oba 2014). Herders moved livestock between the wara and fora herd-management systems depending upon the condition of the grazing lands and family milk needs. Large numbers of animals were sent to the fora herd during the dry season when forage resources become scarce in the grazing lands of the wara herd. Recent increases in human and livestock populations and decreases in the availability of grazing resources coupled with recurrent drought might force pastoralists to manage camel as an adaptation strategy to climate change. In the last few decades, the development of water ponds has also attracted settlements and huge livestock concentration in specific areas for year round grazing. The proliferation of bush encroachment with a decline in forage production is also another problem in terms of affecting cattle population. Major areas of the communal rangelands have already been converted to croplands with even larger areas allocated to ranching (Angassa and Oba 2008). This has greatly restricted the area available for communal grazing and adversely affected dependence of households on cattle husbandry. Overall, the livelihoods of the pastoral communities are subjected to the impact of climate-induced recurrent droughts (Tache and Oba 2010).

\section{Site selection and sampling procedure}

To select the study sites, firstly, we targeted areas with the highest camel population (camel corridor). We then considered areas associated with high vulnerability to the impacts of climate change. Based on these characteristics, Yabello district was selected as a study area. The same criteria were considered to select the study kebeles. ${ }^{1}$ Dharito, Elwaye, and Surupha kebeles of Yabello district were selected to conduct the study.

We employed both purposive and stratified random sampling techniques for household sampling. Sampling went through two important steps. Firstly, the camelholding households were purposively identified as a target population, where 625 households $(\mathrm{HH})$ were listed from the three kebeles. From this target population, 156 households were sampled and distributed to each kebele proportional to its respective target population. Accordingly, $49 \mathrm{HHs}$ from Dharito, $45 \mathrm{HHs}$ from Elwaye, and $62 \mathrm{HHs}$ from Surupha kebeles were selected. This study was mainly focused on Borana community in Dharito and Elwaye kebeles than the Gabra community in Surupha. The reason for this procedure was because the Gabra community members were originally camel herders while the Borana communities were recently engaged in camel management as an adaptive strategy to the impact of recurrent droughts. Each household was interviewed when and why they first adopted camels in response to the impact of droughts and climate change.

\section{Data collection}

Both qualitative and quantitative data collection methods as well as primary and secondary sources on participatory approaches, using a combination of different tools, were used. Primary data were gathered from 156 sample households by employing a household survey (HS), focus group discussions (FGD), key informant interviews (KII), and physical observations of the study areas. Secondary data were gathered from relevant sources such as government agencies, non-governmental organizations, private offices, Internet webs, and literature reviews. Observations on temperature and rainfall trends were obtained from the meteorological record data for the last 27 years. Furthermore, perceptions of pastoralists on trends of temperature and rainfall were collected over the last four Gada periods (Legesse 1973), while information related to camel adoption and population was collected over the last five Gada periods. Gada refers to the Oromo traditional governance 
institution whereby the power from one Gada leader to another Gada leader peacefully transfers every 8 years (i.e., one Gada period lasts for 8 years). Four Gada periods mean the period led by four consecutive Gada leaders (i.e., 32 years). These four Gada periods included the Gada of Boru Guyo from 1984 to 1992, the Gada of Boru Madha from 1992 to 2000, the Gada of Liban Jaldesa from 2000 to 2008, and the Gada of Guyo Goba from 2008 to 2016. The Gada of Jilo Aga from 1976 to 1984 was considered for data collection on camel adoption and trend of camel population. For climate-related parameters, we selected and considered only the last four Gada periods for two reasons: (1) according to our informants, the severity of drought increased during the last three decades, and (2) we assumed that our informants can easily recall the last four Gada periods regarding climate change based on the recent drought events and also from their day-today life experiences. Perceptions of the communities on trends of temperature, rainfall, and local indicators of climate change were recorded in terms of increase, decrease, or no change. First, we assessed evidence of knowledge of the indigenous communities on climate change by looking at temperature and rainfall trends between 1984 and 2013. Then, perceptions of respondents and meteorological data records between 1986 and 2012 were compared to validate the conditions and trends of changing climate. To compare the 27 years of meteorological records with the perception of pastoralists, the records on metrological data were classified into four Gada periods so as to overlap metrological records with the same years in each Gada period to see how they fit with the perceived information. Thus, the results from both meteorological records and perceptions of pastoralists were discussed within each Gada period. Accordingly, trends of the two sets of data were, then, compared to explain the occurrence of climate change in the study areas.

\section{Data analyses}

Quantitative data were analyzed by employing descriptive statistics such as mean values and frequency distributions (in percentages), chi-squared test using the "Statistical Package for Social Science" (SPSS) Software Version 16.0. Statistical significance was determined at $\alpha=0.05$.

\section{Results}

Perceptions of pastoralists on the trend of climate pastoralists perceived that temperature was increasing over the last four Gada periods, while the rainfall pattern showed a general decline. Most respondents (83\%) perceived that temperature was increased considerably during the Gada period of Boru Madha. Similarly, about
$57 \%$ of the respondents confirmed that high temperature occurred during the Gada period of Boru Guyo. Most of the respondents also believed that extremely high temperature occurred during the Gada periods of Liban Jaldessa (92\%) and Guyo Goba (95\%) (Table 1). On the contrary, $34.6 \%$ of the respondents reported that they did not remember anything about the trend of temperature during the Gada period of Guyo Boru (Table 1). However, the proportion of respondents who did not know about the trend of temperature dropped from $34.6 \%$ during the Gada period of Boru Guyo to $1.9 \%$ at the time of Gada Guyo Goba (Table 1).

Our respondents further mentioned that there was a declining trend in terms of the amount of rainfall over the last four Gada periods (Table 1). Overall, 95\% of the respondents perceived that rainfall was greatly reduced during the Gada period of Guyo Goba, while 92.3\% reported a declining trend in the amount of rainfall at the time of Liban Jaldesa (Table 1). Quite the reverse, few respondents $(3.2 \%)$ mentioned that there was an increase in the trend of rainfall over the last four Gada periods (Table 1). The results of the present study clearly showed that there was a significant change in terms of climate as manifested through an increasing trend of temperature and a declining trend of rainfall over the last four Gada periods.

\section{Trends of temperature and rainfall records in the study area (1986-2012)}

Results from meteorological data analyses between 1986 and 2012 showed an increasing trend in terms of average temperature, while the mean annual rainfall showed a declining trend. The existing meteorological data analysis displayed that the mean annual temperature over the study period was above the overall mean, while that of rainfall was below the values for the overall average rainfall (Fig. 1). Generally, the results of the present study showed that there was an increase in the trend of temperature and a decline in rainfall during the latter years of the last decade (Fig. 2).

The overall mean annual temperature for the existing metrological data analysis was $21.76{ }^{\circ} \mathrm{C}$ during the last 27 years. The existing record showed that the minimum and maximum annual temperature values were $18.77{ }^{\circ} \mathrm{C}$ in 1994 and $27.88{ }^{\circ} \mathrm{C}$ in 2010 , respectively. The mean annual rainfall was $502 \mathrm{~mm}$ for the last 27 years. The existing analysis disclosed that the minimum and maximum annual rainfall values were $238.4 \mathrm{~mm}$ in 1986 and $873.8 \mathrm{~mm}$ in 2004, respectively. Overall, there was high inter-annual variability in terms of temperature and rainfall. For example, both the highest temperature and lowest rainfall mean values, in each of the years in 1991, 1997, 2007, 2008, 2010, 2011, and 2012, were recorded. 
Table 1 Respondents' perceptions on trends of temperature and rainfall over the last four Gada periods (1984-2013) in Borana, southern Ethiopia

\begin{tabular}{|c|c|c|c|c|c|c|c|c|}
\hline \multirow[t]{3}{*}{ Gada period } & \multicolumn{8}{|c|}{ Proportion of respondents (\%) } \\
\hline & \multicolumn{4}{|c|}{ Temperature } & \multicolumn{4}{|l|}{ Rainfall } \\
\hline & Increased & Decreased & No change & Do not know & Increased & Decreased & No change & Do not know \\
\hline Boru Guyo (1984-1992) & 57.1 & 0 & 8.3 & 34.6 & 2.6 & 55.1 & 8.3 & 34.0 \\
\hline Boru Madha (1992-2000) & 83.3 & 0 & 5.1 & 11.5 & 0.6 & 85.9 & 3.2 & 10.3 \\
\hline Liban Jaldesa (2000-2008) & 91.7 & 3.2 & 2.6 & 2.6 & 3.2 & 92.3 & 2.6 & 1.9 \\
\hline Guyo Goba (2008-2016) & 94.9 & 1.9 & 1.3 & 1.9 & 3.2 & 95 & 0.6 & 1.3 \\
\hline
\end{tabular}

\section{Perceptions of pastoralists versus meteorological records} on trends of climate

The results showed that the mean annual temperature declined from $21.4{ }^{\circ} \mathrm{C}$ during the Gada period of Boru Guyo (1984-1992) to $20{ }^{\circ} \mathrm{C}$ during the Gada period of Boru Madha (1992-2000). On the contrary, the results showed a constant increase in mean annual temperature during the latter two Gada periods, exceeding $24{ }^{\circ} \mathrm{C}$ during the Gada period of Guyo Goba (2008-2016). Generally, there was an increase in the trend of temperature by $3{ }^{\circ} \mathrm{C}$ during the last two Gada periods. Similarly, the survey results showed that the proportion of respondents who perceived an upward trend in temperature further increased from 57\% respondents during the Gada period of Boru Guyo (1984-1992) to 94\% respondents at the Gada period of Guyo Goba (2008-2016).

The results also showed a downward trend in mean annual rainfall from $507 \mathrm{~mm}$ during the Gada period of Boru Guyo (1984-1992) to $498.4 \mathrm{~mm}$ during the Gada period of Boru Madha (1992-2000). Conversely, the mean annual rainfall showed a slight increase during the following Gada period (2000-2008) and decreased to $421 \mathrm{~mm}$ during the Gada period of Guyo Goba (2008-2016). Generally, mean annual rainfall exhibited a downward trend with a reduction of $77 \mathrm{~mm}$ over the last four Gada periods. The proportions of respondents who reported a downward trend in rainfall substantially increased from 55\%, during the Gada period of Boru Guyo, to 95\% during the Gada period of Guyo Goba. During the latter Gada periods, most respondents felt that the timing and amount of rainfall were greatly reduced. Overall, respondents believed that the declining trend of rainfall over the years was a common phenomenon in their localities.

We confirmed that perceptions of pastoralists were consistent with the existing meteorological analysis although we could not statistically correlate the numerical meteorological data with the immeasurable information based on perceptions of pastoralists. Generally, the existing meteorological analysis captured both the short-term and long-term rainfall and temperature variability whereas perceptions of pastoralists only focused on the overall trends of rainfall and temperature conditions.

\section{Impacts of climate change on livestock}

Drought pattern, natural resource condition, disease prevalence, and livestock productivity

Our respondents articulated the impacts of climate change in terms of changes in drought patterns, status

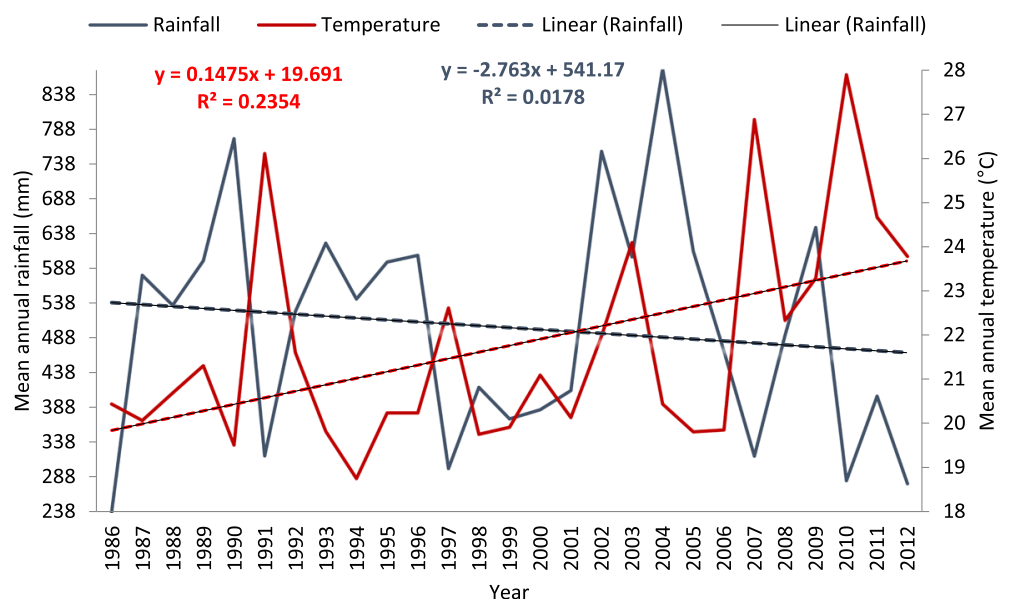

Fig. 1 Mean annual temperature and rainfall of Yabello district in Borana, southern Ethiopia (1986-2012) (equation in red color = temperature, equation in black color = rainfall). Source: Ethiopian National Meteorology Agency (2012) 


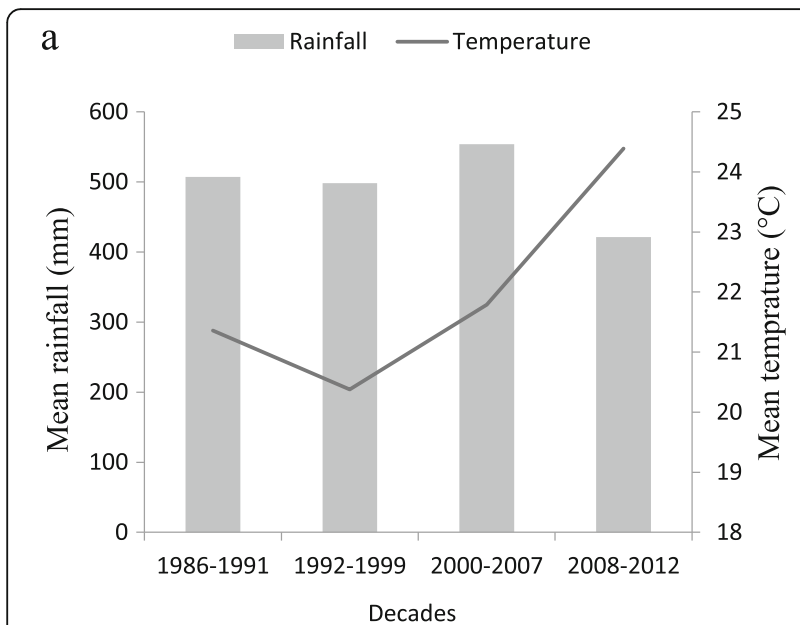

b $\quad$ Temperature increased Rainfall decreased

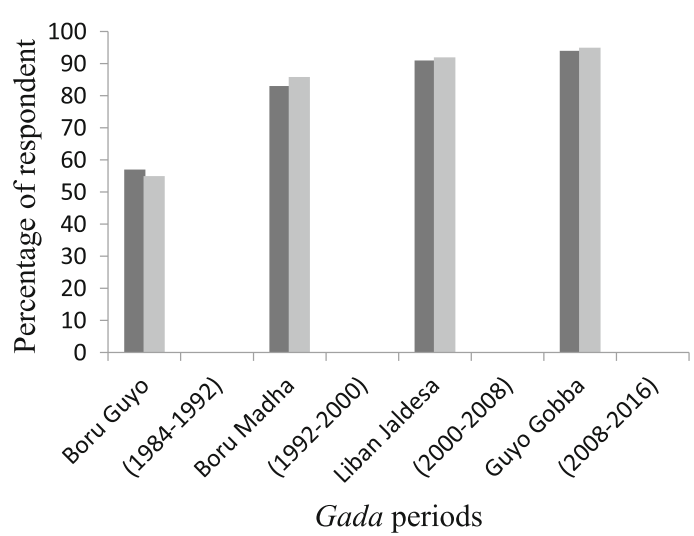

Fig. 2 Meteorological data (a) and pastoralists' perceptions (b) on temperature and rainfall trends over the last four decades in Borana, southern Ethiopia

of natural resources, and changes in the ecology of rangeland vegetation dynamics and composition, disease incidences, and livestock population dynamics. Almost all respondents (97.4\%) perceived that drought frequencies increased, which they considered as an indicator of climate change (Table 2). Similarity, most respondents perceived that water and pasture scarcities were the highest during the last four Gada periods
(Table 2). Furthermore, respondents mentioned the increased prevalence of livestock diseases (83.3\%), reduction in livestock feed resources due to shrinkage of grazing lands (95\%), shortage of water (91\%), decline in milk production and calving rate, and increased calving interval (95\%) were additional indicators of climate change (Table 2).

\section{Livestock mortality during the drought of Gada Guyo Goba} From their recent past recalls, respondents mentioned that a devastating drought had resulted in a massive loss of the cattle population during the Gada period of Guyo Goba (i.e., in 2011). Respondents reported that there was a complete failure of rain for two consecutive rainy seasons (i.e., during the main and short rainy seasons). According to the views of the respondents, the overwhelming drought of 2011 had caused a huge damage on the cattle population in the study areas, creating more destitute pastoral households.

Respondents mentioned that on average, there were losses of about seven cattle, three sheep, and one goat per household during the drought of 2011 (Fig. 3). However, respondents highlighted that deaths among camels and equines were virtually non-existence during the same drought year. Perceptions of respondents also showed that the level of livestock mortality was higher for cattle and sheep than for goats. Respondents maintained that the capacity of camels to withstand the impacts of climate change was a key factor for their choice to manage camels to adapt to the changing environmental conditions.

Few of the respondents in Dharito (8.8\%) and Elwaye (4.4\%) kebeles mentioned that they started managing camels as an adaptation strategy because of the vulnerability of cattle during multiple droughts (Fig. 4). However, many of the respondents in Dharito (30.6 and 32.7\%) and Elwaye (33.3 and 33\%) reported that they started managing camels as a result of frequent droughts that occurred during the Gada periods of Boru Madha (1992-2000) and Liban Jaldesa (2000-2008), respectively (Fig. 5). The number of camel population managed by the communities during the Gada period of Jilo Aga (1976-1984) was very low (Fig. 6). However, the number

Table 2 Respondents' perceptions on trends of local indicators of climate change in terms of drought frequencies, scarcity of water and pasture, disease prevalence, and reduced milk production in Borana, southern Ethiopia

\begin{tabular}{|c|c|c|c|c|c|c|}
\hline \multirow[t]{2}{*}{ Indicators } & \multicolumn{2}{|l|}{ Increased } & \multicolumn{2}{|l|}{ Decreased } & \multicolumn{2}{|l|}{ No change } \\
\hline & Frequency & $\%$ & Frequency & $\%$ & Frequency & $\%$ \\
\hline Drought frequency & 152 & 97.4 & 1 & 0.6 & 3 & 1.9 \\
\hline Scarcity of water & 7 & 4.5 & 142 & 91 & 7 & 4.5 \\
\hline Scarcity of pasture & 5 & 3 & 148 & 95 & 3 & 2 \\
\hline Disease prevalence & 130 & 83.3 & 9 & 5.8 & 17 & 10.9 \\
\hline Reduced milk production & 8 & 5.1 & 147 & 94 & 1 & 0.6 \\
\hline
\end{tabular}




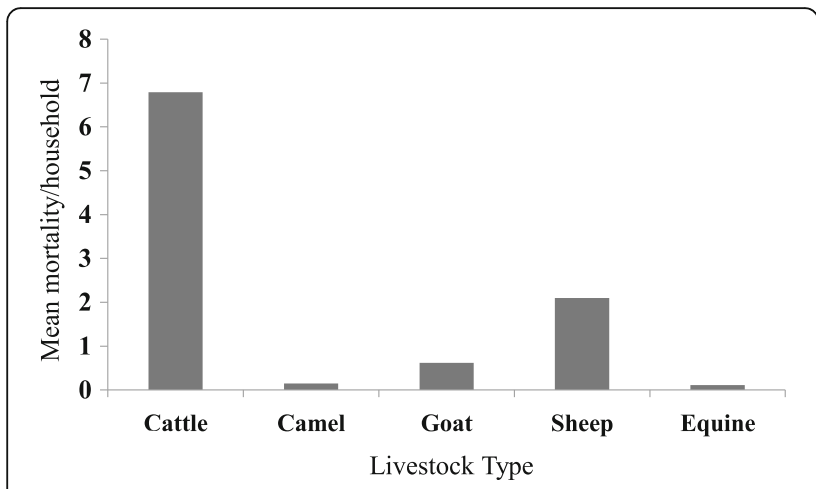

Fig. 3 Perceptions of pastoralists indicating mean values of livestock mortality per household during the 2011 drought event in the study areas in Borana, southern Ethiopia

of camel population managed by the pastoralists increased quickly during the three successive Gada periods with the incidence of recurrent droughts (Fig. 6).

Respondents further reported that they acquired camels through different means. These included the purchase of camels from local markets, inheritance and gifts from relatives, post drought restocking, and in some cases raiding of camels during tribal conflicts (Fig. 4). Households in Dharito (65.3\%) and Elwaye (77.7\%) kebeles reported that they directly purchased camels from the local markets, while few of them responded that they acquired camels through inheritance and/or gift from their relatives, as well as post drought restocking. About $75.8 \%$ of the respondents from Surupha kebele explained that they acquired camels through inheritance, while only few of them expressed that they acquired camels through gifts from relatives (14.5\%) and purchase of camels from the local markets (9.7\%) (Fig. 5).

Respondents from the Borana community asserted that they had purchased and managed camels for diversification because of their ability to adapt to frequent droughts and their prolific milk production. Generally, the increase in the trend of camel population in the Borana region of southern Ethiopia was associated with the changing patterns of climatic and drought events (Fig. 5).

At the time of the survey, respondents (41\%) explained that the milk production potential of camels was the most important indicator that makes them unique and more important than cattle and goats. They also believed that the expansion of bush encroachment (30.8\%) and the ability of camels to withstand frequent droughts (28\%) made them as the most preferred animals by pastoralists (Table 3). Overall, the camel preferences of respondents to other livestock types and the indicators they used regarding the unique quality of adaptation of camels to extreme environmental conditions were constant.

\section{Discussion}

\section{Evidence of climate change: pastoralist perceptions} versus meteorological records

In the Borana areas of southern Ethiopia, camels are increasingly managed by the pastoral households because of the incidences of severe droughts. Observations of pastoralists indicate the existence of extensive change in terms of rainfall with an increasing trend of temperature and frequent droughts over the last four Gada periods (1984-2016). These suggest that perceptions of low rainfall, rising of temperatures, and frequent droughts by the respondents are consistent with results from the existing meteorological analyses. Opinions of pastoralists further indicate that climate change is happening as they witnessed constant increase in temperature and decline in rainfall over the years. Furthermore, experiences of pastoralists show that the current rainfall is highly erratic with short duration. The reflection of pastoralists on the declining amount of rainfall agrees with the findings of Riché et al. (2009), who reported a declining trend of rainfall in Borana and Shinile Zones of Ethiopia over the

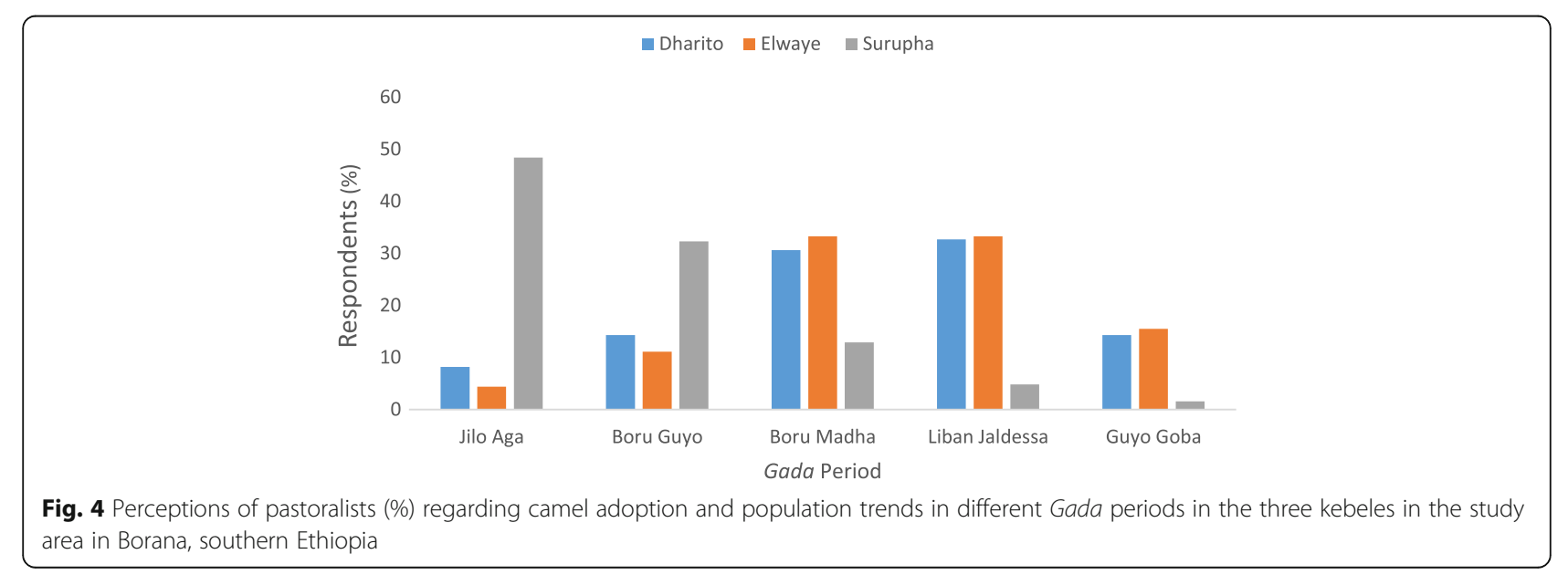


Dharito Elwaye Surupha

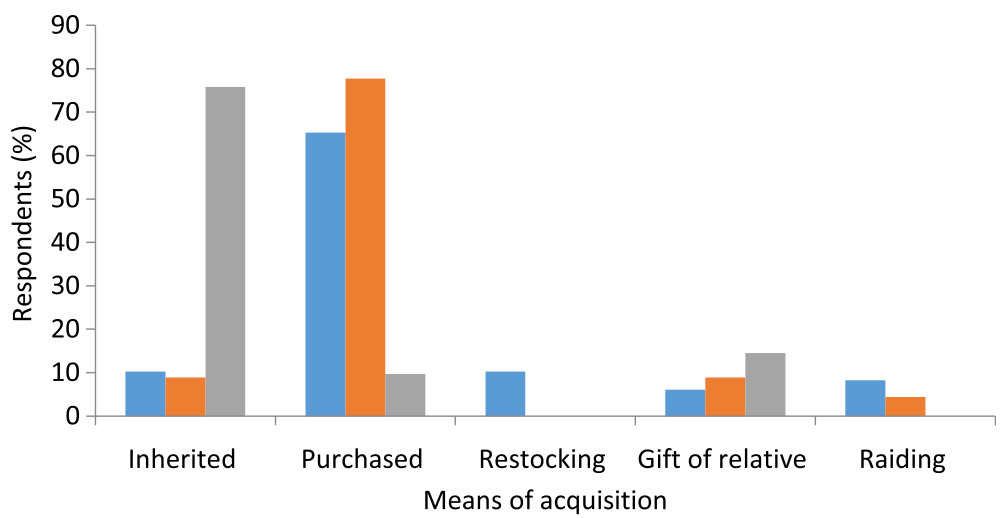

Fig. 5 Perceptions of pastoralists (\%) regarding means of camel acquisition between the Gada period of Jilo Aga and Guyo Goba in the three kebeles in the study area in Borana, southern Ethiopia

last three decades. As reported in previous studies (Desta and Coppock 2002; Angassa and Oba 2007, 2008), the Borana pastoralists can easily recall past climatic events such as heavy rainfall and severe droughts in relation to important social events that took place during a particular Gada period. Wassie and Fekadu (2014) have also reported a similar finding indicating that the Borana pastoralists can easily recall past events, including their age, by referring to a particular Gada period. For example, the Borana oral history suggests that two historical weather-related disasters that the Borana people faced during two different Gada periods are still fresh in the memories of the pastoralists. Those events were considered as "the most miserable life situation," locally nicknamed "Cinna Gada Liiban Jaldeessaa"

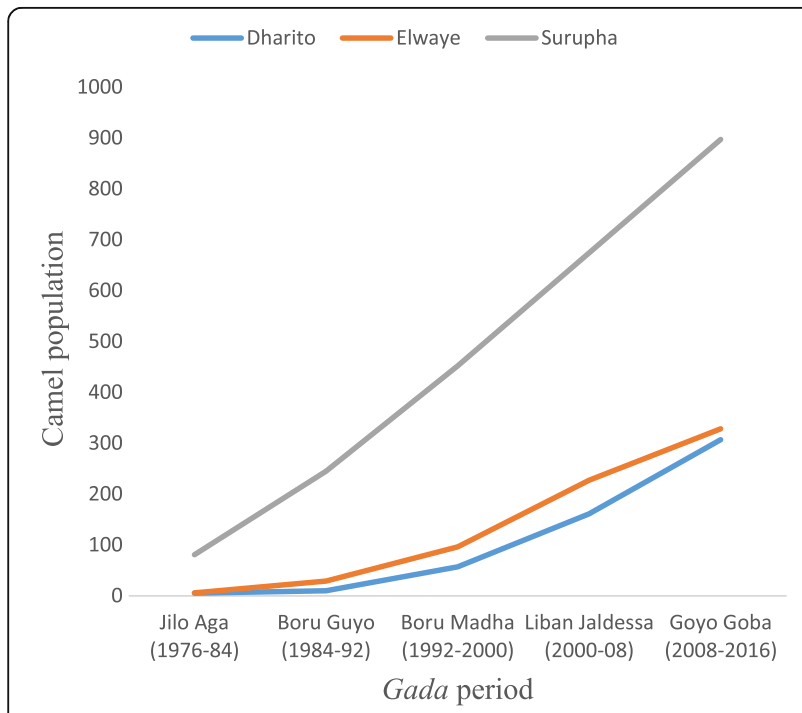

Fig. 6 Trend of camel population over the last five Gada periods owned by respondents in the three kebeles in the study area in Borana, southern Ethiopia
(1888-1896), and "the most abundant life conditions," locally nicknamed "Badhaadha Gada Adii Dooyyoo" (1896-1904). Both events are being used as proverbs by members of the Borana society. Some of the given names of Borana people are linked to environmental and social events (rain, drought, war, etc.) that might have taken place at the time when someone was born. For example, "Roba" is a given name to someone who is born during a good season of sufficient rainfall, while "Bonaya" is a given name for a person born during a period of severe drought. Generally, the changing patterns of climate such as rainfall are memorialized within the culture of the Borana people.

The results from the meteorological analyses showed a constant increase in temperature with a high variability of rainfall between 1986 and 2012. Both temperature and rainfall trends demonstrate a clear deviation from the overall mean values for the same period. PFE (2010) has reported a similar situation where meteorological records between 1957 and 2006 display the mean annual rainfall data with a high inter-annual variability and an increasing trend of temperature. Thus, we confirmed a similar trend between perceptions of pastoralists and results from the existing meteorological analyses. Both observations of pastoralists and the meteorological records further confirmed that the rise in temperature is constant, while rainfall is highly fluctuating. Such similarities between perceptions of pastoralists and the existing meteorological records suggest that pastoralists are aware of the impact of climate change. Generally, the awareness of pastoralists about climate change could help them to respond appropriately to the changes in their local environment for adaptation and mitigation. In another study, Wassie and Fekadu (2014) have also shown that perceptions of communities are consistent with the four decades of climate analyses. 
Table 3 Respondents' perceptions on driving factors for camel management as an adaptation strategy in the three kebeles in the study area in Borana, southern Ethiopia

\begin{tabular}{|c|c|c|c|c|c|c|c|c|c|}
\hline \multirow[t]{2}{*}{ Driving factor } & \multicolumn{2}{|c|}{ Dharito $(n=49)$} & \multicolumn{2}{|c|}{ Elwaye $(n=45)$} & \multicolumn{2}{|c|}{ Surupha $(n=62)$} & \multicolumn{2}{|c|}{ Overall $(n=156)$} & \multirow{2}{*}{$\begin{array}{l}\text { Test } \\
x^{2} \text { value }\end{array}$} \\
\hline & Frequency & $\%$ & Frequency & $\%$ & Frequency & $\%$ & Frequency & $\%$ & \\
\hline Milk potential & 19 & 38.8 & 18 & 40 & 27 & 43.5 & 64 & 41.0 & 0.141 \\
\hline Adaptability & 16 & 32.7 & 12 & 26.7 & 16 & 25.8 & 44 & 28.2 & \\
\hline Bush expansion & 14 & 28.6 & 15 & 33.3 & 19 & 30.6 & 48 & 30.8 & \\
\hline Total & 49 & 100 & 45 & 100 & 62 & 100 & 156 & 100 & \\
\hline
\end{tabular}

\section{Impacts of climate change on pastoral production}

The findings revealed that climate change has intensified the rate of recurrence and severity of droughts on cattle mortality. An elder respondent from Dharito kebele explained the situation as follows: "In the past, they used to be amazed if drought occurred once in a Gada period, i.e., every eight years. At present, however, he said it is astonishing if the drought is not occurring every year. He went on saying that there were times when rainfall failed completely for two consecutive rainy seasons, both during the main and short rainy seasons. Besides the frequencies, the severity of the current droughts often entails unbearable consequences." A similar finding by Yohannes and Mebratu (2009) has also indicated that the failure of rain for consecutive seasons has been common in Borana pastoral areas of southern Ethiopia.

The findings also suggest that the increase in temperature, frequent droughts, and low rainfall are major indicators of climate change that further contribute to the degradation of natural resources. Similarly, Donald et al. (2012) have indicated that climate-induced stresses threatened the quantity and quality of drinking water and pasture for livestock survival. The expansion of invasive woody species in the study area might also contribute to the reduction of perennial grasses (Oba 1998). Previous studies (Angassa and Baars 2000; Oba et al. 2000; Tolera and Abebe 2007; Angassa and Oba 2008) have also documented that the availability and quality of valuable forage species are declining in the rangelands of southern Ethiopia as a result of bush encroachment. The deterioration of grass resources with the expansion of bush encroachment is mainly problematic for cattle population although camels and goats are able to adapt to the changing ecological conditions of the study area.

The present study confirms that drought-induced feed scarcity has worsened the vulnerability of cattle to the impacts of droughts (Angassa and Oba 2007). The drought of 2011 could be a good example of the recent past in terms of the massive loss of cattle population in the region. Hurst et al. (2012) have concluded that the drought of 2011 has caused starvation and death of many livestock in southern Ethiopia. Similarly, Oxfam International (2010) has reported that climate-induced recurrent droughts have caused the loss of thousands of livestock in Borana pastoral areas. Pantuliano and Pavanello (2009) have also reported that the pastoral areas in the Ethiopia-Kenya and Somalia borders have suffered a huge loss of livestock (up to $70 \%$ ) in 2006. However, observations of pastoralists showed that the impact of drought does not equally threaten all livestock species. According to pastoralists' insights, drought-induced livestock losses are the highest among cattle and sheep, while camels and goats are tolerant. This implies that camels are most likely the best animals to withstand the severity of drought. Thus, the efforts of Borana pastoralists to utilize the unique potential of camels for livelihood diversification might be a practical lesson for future sustainable development and alleviation of poverty across the drylands of Africa. The results of the present study also suggest that camel is most likely the only appropriate animal that could be used by African pastoralists for adaptation and mitigation to the impact of climate change.

\section{Camel adoption, increased camel population, and driving factors among the Borana society}

The results show that camel husbandry is a recent experience among the Borana pastoralists. Camel management by the formerly cattle herding communities is an emerging issue that might suggest the responses of communities to low rainfall, persistent droughts, and shifts in the ecology of rangeland vegetation. Coppock (1994) has pointed out that the Borana herders were initially reluctant to keep camels and refused to consume their products such as milk and meat. However, their observations indicate that there is a growing interest among the Borana pastoral households in camel management. They also pointed out that they have learned the value of camel husbandry from the neighboring Gabra community. Most respondents have indicated that they have acquired camels through the direct purchase of the animal from the local markets (Desta and Coppock 2004). This reflects that the purchase of camels from local markets significantly contributed to the increase in camel population during the latter two Gada periods. Despite the increase in camel population in the study areas, others (Wassie and Fekadu 2014) have argued that the number of camel holdings among the Borana pastoralists is still low given the challenges of frequent droughts. 
Generally, preference of pastoralists in terms of camel management seems an intelligent move in relation to the changing ecology of rangeland vegetation dynamics (Coppock 1994; Oba 1998; Angassa and Oba 2008), high milk production potential of camels, and their capacity to withstand harsh environmental conditions. According to Abdi (2010), camels earned the nickname "Ship of the Desert" due to their ability to survive under harsh climatic conditions. Overall, camel management by the Borana herders reflects a strategic adaptation to the existing local conditions. It further reflects responses of communities to the impacts of multiple droughts for livelihood diversification options in order to ensure the food security of their families.

Perceptions of respondents indicate that camels provide outstanding benefits in terms of enhancing drought resilience, insurance against risks of food insecurity, and good sources of revenue to eradicate poverty when compared with other livestock types. The contributions that camels make to milk production for home consumption and sale during severe droughts may also be one of the factors that inspires the Borana pastoralists to manage camel as an adaptation strategy. Musinga et al. (2008) have shown that the constant supply of camel's milk could have a significant impact in strengthening drought resilience among pastoralists. The reflections of pastoralists also showed that the lactation period of camels is much longer than that of other livestock types. According to CARE Ethiopia (2009), milk produced from a single camel can be sufficient for family members even during the drought periods. The affirmations of respondents concerning the influence of environmental change for camel adoption are in contrast to the report by Desta and Coppock (2004), who suggested that the Borana pastoralists engaged in camel husbandry through raiding camels from the neighboring camel herding pastoralists.

\section{Conclusions}

This study focused on generating evidence of camel management as an adaptation strategy to climate change by the Borana pastoralists. The increasing interest in camel management as an adaptation strategy in southern Ethiopia by the former cattle pastoralists can be understood in terms of livelihood diversification options to alleviate poverty. This is mainly because of the responses of pastoralists to low rainfall and vulnerability of cattle to frequent droughts as emerging issues.

We confirmed that both perceptions of pastoralists and meteorological records showed a constant increase in temperature, a downward trend in rainfall coupled with frequent droughts. Respondents believed that experiences of low rainfall below the normal average and recurrent droughts resulted in deterioration of natural resources, increased disease incidence, and risks of droughts for cattle deaths. Pastoralists confirmed that camels have high adaptive capacity to withstand the impacts of climate change, which reflects the high economic value of camels in terms of climate change adaptation and mitigation. Assessments of respondents further confirmed that camels are highly valued for food security and poverty alleviation although the value of camel was overlooked in the past. Generally, the results indicated that camel management is a novel approach in terms of livelihood diversification options and climate resilience for sustainable development. We suggest promotion and value addition to camel milk for ensuring food security of pastoral households as a measure towards poverty alleviation.

\section{Endnotes \\ ${ }^{1}$ Kebele is the lowest administrative unit in Ethiopia.}

\section{Acknowledgements}

The authors acknowledge Feinstein International Centre of Tufts University and International Institute for Environment and Development (IIED) for the financial assistance to conduct the research work. We also thank those pastoral communities and officials in the study areas for their cooperation and assistance during fieldwork. We are grateful for the insightful comments given by two anonymous reviewers for the improvement of the quality of our manuscript. The authors also thank Professor Demel Teketay for the proof reading of the final version and valuable comments.

\section{Funding}

Funding bodies have no role in the design of the study and data collection, analysis, and interpretation of data and writing of the manuscript.

\section{Authors' contributions}

GW conducted the field research, analyzed the data, and drafted the manuscript. MT designed the research, interpreted the results, and helped in the manuscript writing. AA interpreted the results and fully participated in the whole process of write-up of the manuscript. All authors revised the manuscript and read and approved the final version.

\section{Competing interests}

The authors declare that they have no competing interests.

\section{Publisher's Note}

Springer Nature remains neutral with regard to jurisdictional claims in published maps and institutional affiliations.

\section{Author details}

${ }^{1}$ Wondo-Genet College of Forestry and Natural Resource, Hawassa University, Shashamane, Ethiopia. ${ }^{2}$ Department of Animal Science and Production, Botswana University of Agriculture and Natural Resources, Gaborone, Botswana

Received: 20 January 2017 Accepted: 26 June 2017

Published online: 31 July 2017

\section{References}

Abdi A (2010) Town camels and milk villages: the growth of camel milk marketing in the Somali Region of Ethiopia. Future of Agricultures Consortium (FAC) Research Update 003, Pastoralist Theme. http://www.future-agriculture.org/. Abebe T (2007) Climate change national adaptation programme of action (NAPA) of FDRE. National Meteorological Agency (NMA), Ethiopia, Addis Ababa Ahmad S, Yaqoob M, Hashmi N, Zaman MA, Tariq M (2010) Economic importance of camel: a unique alternative under crisis. Pakistan Vet J 30(4):191-197 
Ahmed T, Kanwal R (2004) Biochemical characteristics of lactic acid producing bacteria and preparation of camel milk cheese by using starter culture. Pakistan Vet J 24(2):87-91

Angassa A (2011) Effects of drought on cattle herd dynamics and its implication on local livelihood systems in Borana, Ethiopia. Hohenheim University, Food Security Centre, Stuttgart. Brief Series No.1: 1-6

Angassa A, Baars RMT (2000) Ecological condition of encroached and nonencroached rangelands in Borana, Ethiopia. Afr J Ecol 38(4):321-328

Angassa A, Oba G (2007) Relating long-term rainfall variability to cattle population dynamics in communal rangelands and a government ranch in southern Ethiopia. Agr Syst 94(3):715-725

Angassa A, Oba G (2008) Herder perceptions on impacts of range enclosures, crop farming, fire ban and bush encroachment on the rangelands of Borana, southern Ethiopia. Hum Ecol 36(2):201-215

Calvosa C (2009) Livestock and climate change. Livestock thematic paper. International Fund for Agricultural Development, Rome, Italy, www.ifad.org/ Irkm/index.htm

Campbell DJ (1999) Response to drought among farmers and herders in southern Kajiado district, Kenya: a comparison of 1972-1976 and 1994-1995. Hum Ecol 27(3):377-416

CARE Ethiopia (2009) Value chain analysis of milk and milk products in Borana pastoralist area: regional resilience enhancement against drought project. Yonad Business Promotion and Consultancy PLC Addis Ababa, Ethiopia

Coppock DL (1994) The Borana plateau of southern Ethiopia: synthesis of pastoral research, development and change, 1980-91. International Livestock Research Institute (ILRI), Addis Ababa, Ethiopia

Desta S, Coppock DL (2002) Cattle population dynamics in the southern Ethiopian rangelands, 1980-97. J Range Manage 55:439-451

Desta S, Coppock DL (2004) Pastoralism under pressure: tracking system change in southern Ethiopia. Hum Ecol 32(4):465-486

Donald B, Rabecca R, Chanakira KC, Mutuso D, David D, Medicine M, Davison M, Prisca M, Sherpard Z (2012) Climate change impacts, vulnerability and adaptation in Zimbabwe. IIED Climate Change Working Papaer Series No. 3. December 2102. IIED www.iied.org

Ellis EJ, Swift MD (1988) Stability of African pastoral ecosystems: alternate paradigms and implications for development. J Range Manage 41:450-459

FAO (2010) Adding value to livestock diversity marketing to promote local breeds and improve livelihoods. FAO Animal Production and Health Paper. No. 168, Rome

Farah Z (1996) Camel milk, properties and products. Laboratory of Dairy Science, Swiss Federal Institute of Technology

Gardner I (2012) Pastoralist access to livestock health services in Tanzania: implications for climate change-driven disease. Colorado State University Fort Collins, CO 80523-1644.

Haile A, Yilma Z (2009) Climate change, livestock and people: challenges, opportunities, and the way forward. Ethiopian Society of Animal Production (ESAP) (Eds). Proceedings of the 17th Annual conference held in Addis Ababa, Ethiopia, September 24 to 26, 2009. ESAP, Addis Ababa.

Hartmann I, Sugulle A (2009) The impact of climate change on pastoral societies of Somaliland. Candlelight for Health, Education \& Environment, Somalia

Hesse C, Cotula L (2006) Climate change and pastoralists: investing in people to respond to adversity. Sustainable Development Opinion. International Institute for Environment and Development (IIED). www.iied.org.

Hounam CE, Burgos JJ, Kalik MS, Palmer WC, Rodda J (1975) Drought and agriculture. Report of the CAgM Working Group on Assessment of Drought. Technical Note No. 138. WMO Publication No. 392, Geneva.

Hurst M, Jensen N, Pedersen S, Sharma A, Zambriski J (2012) Changing climate adaptation strategies of Borana pastoralists in southern Ethiopia. Working paper no. 15 Cali, Colombia: CGIAR Research Program on Climate Change, Agriculture and Food Security (CCAFS). www.ccafs.cgiar.org.

IPCC (2001) Climate change: the scientific basis. Contribution of working group I to the third assessment report of the intergovernmental panel on climate change. Cambridge University Press, Cambridge, UK and New York, USA

IPCC (2007) Climate change: mitigation. Contribution of working group III to the fourth assessment report of the IPCC. Cambridge University Press, Cambridge, UK and New York, USA

IPCC (2012) Managing the risks of extreme events and disasters to advance climate change adaptation. A special report of working groups I and II of the intergovernmental panel on climate change [Field, C.B., V. Barros, T.F. Stocker, D. Qin, D.J., Dokken, K.L., Ebi, M.D., Mastrandrea, K.J., Mach, G.K., Plattner, S.K., Allen, M. Tignor, and P.M. Midgley (eds.)]. Cambridge University Press, Cambridge, UK, and New York, NY, USA, 582 pp.
Legesse A (1973) The Gada: three approaches to the study of African society The Free Press, New York

McCabe JT (2006) Cattle bring us to our enemies. Turkana ecology, politics, and raiding in a disequilibrium system. Hum Ecol 34(1):147-149

Megersa B, Regasssa A, Kumsa K, Abuna F (2008) Performance of camels (Camelus dromedrius) kept by pastoralists with different degrees of experience in camel keeping in Borana, southern Ethiopia. Anim Sci J 79(4):534-541

Megersa B, Markemann A, Angassa A, Ogutu JO, Piepho HP, Zárate AV (2014) Livestock diversification: an adaptive strategy to climate and rangeland ecosystem changes in southern Ethiopia. Hum Ecol 42(4):509-520

Musinga M, David K, Kivolonzi P (2008) The camel milk industry in Kenya: the potential of camel milk from Isiolo district. Netherland Development Organization (SNV)

Naess OL, Sullivan M, Khinmaung J, Philippe C, Otzelberger A (2010) Changing climates changing lives: adaptation strategies of pastoral and agro-pastoral communities in Ethiopia and Mali. Action Contre La Faime, International

Oba G (1998) Assessments of indigenous range management knowledge of the Borana pastoralists in southern Ethiopia. Borana Lowland Pastoral Development Program/GTZ, Consultancy paper, Negelle/Borana May 1998.

Oba G (2014) Climate change adaptation in Africa: an historical ecology. Routledge Taylor and Francis Group, London and New York

Oba G, Stenseth NC, Lusigi WJ (2000) New perspectives on sustainable grazing management in arid zones of sub-Saharan Africa. Bioscience 50:35-51

Omolo NA (2010) Gender and climate change-induced conflict in pastoral communities: case study of Turkana in north-western Kenya. African Journal of Conflict Resolution 10(2):81-102

Opiyo F, Wasonga O, Nyangito M, Schilling J, Munang R (2015) Drought adaptation and coping strategies among the Turkana pastoralists of northern Kenya. Int J Disaster Risk Sci 6:295-309

Oxfam International (2010) (Senait Regassa, Christina Givey, and Gina E. Castillo, (Eds.)) Rain does not come on time any more: poverty, vulnerability, and climate variability in Ethiopia, Addis Ababa Ethiopia.

Pantuliano S, Pavanello S (2009) Taking drought into account: addressing chronic vulnerability among pastoralists in the Horn of Africa. Humanitarian Policy Group (HPG), Policy Brief 35. Overseas Development Institute, London

Pastoralist Forum Ethiopia (PFE) (2010) Climate change and pastoralism: implication for sustainable pastoral development. Pastoralist Forum Ethiopia. Report of $5^{\text {th }}$ National Conference on Pastoralism, Addis Ababa, Ethiopia.

Riché B, Hachileka E, Awuor BC, Hammill A (2009) Climate related vulnerability and adaptive capacity in Ethiopia's Borana and Somali. International Institute of Sustainable Development and International Union for Conservation of Nature (IISD and IUCN), Commissioned by CARE International.

Sahel SOS (2010) Pastoralism in Ethiopia: its total economic values and development challenges. SOS, Sahel Ethiopia

Tache B (2010) Mapping with customary institutions in southern Ethiopia. Save the Children US and SOS Sahel Ethiopia, Addis Ababa, Ethiopia

Tache B, Oba G (2010) Is poverty driving Borana herders in southern Ethiopia to crop cultivation? Hum Ecol 38:639-649

Tiki W, Oba G, Tvedt T (2013) An indigenous time-related framework for reconstructing the impact of disasters on ancient water systems in southern Ethiopia, 1560-1950. J Hist Geogr 41:33-43

Tolera A, Abebe A (2007) Livestock production in pastoral and agro-pastoral production systems of southern Ethiopia. Livestock Research for Rural Development 19: Article \#177. http://www.Irrd.org//rrd19/12/tole19177.htm.

UNFCCC (2007) Climate change: impacts, vulnerabilities and adaptation in developing countries., United Nations Framework Convention on Climate Change

Wako G (2015) Economic value of camel milk in pastoralist communities in Ethiopia: findings from Yabello district. IIED Country Report. IIED, London

Wassie B, Fekadu B (2014) The impact of climate change on pastoral production systems: a study of climate variability and household adaptation strategies in southern Ethiopian rangelands. World Institute for Development Economics Research (WIDER), Working Paper, United Nations University (UNU)

Watson EE, Kochore HH, Dabasso BH (2016) Camels and climate resilience: adaptation in northern Kenya. Hum Ecol 44:701-713

Yohannes G, Mebratu K (2009) Local innovation in climate-change adaptation by Ethiopian pastoralists. PROLINNOVA-Ethiopia and Pastoralist Forum Ethiopia (PFE), Addis Ababa, Ethiopia 